\title{
Hipnoterapi: Proses dan Dampak Religiulitas dalam Menyelesaikan Kasus Kenakalan Seorang Remaja
}

\author{
Rohimi \\ Program Pascasarjana Interdisciplinary Islamic Studies \\ UIN Sunan Kalijaga Yogyakarta
}

Korespodensi dengan Penulis:

Rohimi : Telp: 087853180766

E-mail: dinobastian11@gmail.com

\section{Keywords: \\ Rehabilitation \\ Process, Juvenile \\ Delinquency, the \\ Practice of \\ Hypnotherapy}

\section{Kata kunci: \\ Proses \\ Rehabilitasi, \\ Kenakalan \\ Remaja, Praktik \\ hipnoterapi}

\begin{abstract}
This study examines the process of rehabilitation of juvenile delinquent muslim clients in the practice of hypnotherapy. This study uses qualitative methods or field research, where the researchers immediately jumped into the research location located at the Institute of Indonesian Hypnotherapist Association (IHI) Yogyakarta. The method of data collection in this study through in-depth interviews, observation and documentation. The results of this study that the rehabilitation process of juvenile delinquent clients in the practice of hypnotherapy uses several methods of hypnotherapy that are used to restore the nature of a child to be a good person and stop doing negative things. Some methods of rehabilitation of juvenile delinquency clients carried out in the practice of hypnotherapy, namely (a) suggestibility tests and per-induction interviews, collect information related to client problems to facilitate the rehabilitation process (b) induction, entering the client's consciousness to the subconscious mind. easy to rehabilitate from the problems faced by clients (c) deepening, where teenage clients have gone through an unconscious stage and from the guiding stage to being given motivation to blend positively (d) depth level test, the stage of seeing a result of rehabilitation of juvenile delinquency clients (e) termination, the stage of returning a conscious mind of a client.
\end{abstract}

\begin{abstract}
Abstrak
Studi ini mengkaji tentang proses rehabilitasi klien kenakalan remaja muslim pada praktik hipnoterapi. Penelitian ini menggunakan metode kualitatif atau penelitian lapangan (field research), dimana peneliti langsung terjun ke lokasi penelitian yang berlokasi di Lembaga Ikatan Hipnoterapis Indonesia (IHI) Yogyakarta. Metode pengumpulan data dalam penelitian ini melalui metode wawancara mendalam, observasi dan dokumentasi. Hasil dari penelitian ini bahwa proses rehabilitasi klien kenakalan remaja pada praktik hipnoterapi mengunakan beberapa metode hipnoterapi yang digunakan untuk mengembalikan fitrah seorang anak menjadi pribadi yang baik dan berhenti melakukan hal-hal
\end{abstract}


negatif. Beberapa metode rehabilitasi klien kenakalan remaja yang dilakukan pada praktik hipnoterapi yakni (a) tes sugestibilitas dan perinduction interview, mengumpulkan informasi terkait permasalahan klien agar memudahkan proses rehabilitasi (b) induction, memasuki tahap peralihan kesadaran klien ke pikiran bawah sadar, agar lebih mudah untuk direhabilitasi dari permasalahan yang dihadapi oleh klien (c) deepening, dimana klien anak remaja sudah melalui tahap tidak sadar dan mulai tahap pembimbingan untuk diberikan motivasi berbaur positif $(\mathrm{d})$ depth level test, tahap melihat suatu hasil dari rehabilitasi klien kenakalan remaja (e) termination, tahap pengembalian pikiran sadar seorang klien.

\section{PENDAHULUAN}

Kenakalan remaja merupakan salah satu bentuk patologi bagi masyarakat, padahal secara etimologis remaja merupakan generasi bagi suatu negara. Rasionalnya, anak sejak masa remaja harus didoktrinkan dan diajarkan lebih bermoral beretika agar tidak menjadi generasi yang terjerumus pada hal-hal yang negatif. Perhatian dari orang tua sangat penting bagi perkembangan anak, terutama ketika anak menginjak masa remaja. Ini beralasan karena memang pada masa remaja merupakan masa pencarian jati diri seorang anak untuk lebih permisif atas suatu kehidupan. Masa remaja adalah masa peralihan antara usia seorang anak ke masa dewasa yaitu antara umur 13-18 tahun. ${ }^{1}$ Sehingga anak pada masa remaja harus dibina dan dibimbing dengan hal-hal positif, mengingat eksistensi remaja sangat dibutuhkan menjadi generasi suatu bangsa. Sugeng melihat remaja juga merupakan dari makhluk hidup yang juga akan menerima kematian, sehingga dengan usia tersebutm, setidaknya anak benar-benar dibina agar memiliki tumbuh kembang yang stabil. ${ }^{2}$

Saat proses pencarian jati diri, seorang remaja membutuhkan suatu bimbingan, kasih sayang, dan pendidikan agar tidak terjerumus ke dalam hal-hal yang membuat emosional dan kepribadian seorang anak menjadi negatif. Setiap anak akan menjadi orang yang memiliki kepribadian dan emosional yang baik ketika benar-benar selalu disandingkan dengan hal-hal positif terutama kasih sayang dari orang tua. Melihat anak pada masa remaja tidak hanya kesulitan dalam mengendalikan ego, tetapi pada masa krisis ini, seorang anak kerap kali berhadapan dengan hal-hal yang tidak diinginkan, padahal secara kesadaran sangat enggan untuk mampu memecahkan permasalahannya dengan maksimal. ${ }^{3}$

${ }^{1}$ Ida Nor Shanty, Suyahmo, dan Slamet Sumarto, “Faktor Penyebab Kenakalan Remaja pada Anak Keluarga Buruh Pabrik Rokok Djarum di Kudus", Unnes Civic Education Journal, Vol. 1, No. 2, 2015. hlm 2.

${ }^{2}$ Sugeng Sejati, "Implikasi Egosentris dan Spritual Remaja dalam Mencapai Perkembangan Identitas Diri," Jurnal Ilmiah Syiar, Vol 19, No 1 2019. hlm 104.

${ }^{3}$ Ibid., hlm. 106. 
Dalam upaya mewujudkan hal tersebut, dibutuhkan peran penting dari orang yang terdekat dengan anak yaitu ibu. Ibu dianggap sebagai orang yang sangat mengenal seluk beluk anak, mengasuh anak, mendidik anak di lingkungan keluarga. Seorang ibu memiliki keterkaitan emosional dengan si anak. Agar mampu melahirkan kepribadian yang baik, maka pada masa remajanya harus benar-benar diperhatikan dan diprioritaskan akan hal-hal yang baik. Banyak fase perkembangan seorang anak dalam membangun tumbuh kembang anak pada tahap kepribadian yang baik. Salah satu fase yang penting dan menjadi pusat perhatian adalah fase remaja. 4

Pada masa remaja, serang anak harus diberi sugesti positif dan menjaganya agar tidak terjerumus ke dalam hal-hal yang negatif. Karena kenakalan remaja merupakan tingkah laku yang melampaui batas toleransi orang lain dan lingkungannya. Tindakan ini merupakan perbuatan yang melanggar hak asasi menusia (HAM) bahkan sampai melanggar tindak pidana. ${ }^{5}$

Seorang anak pada masa remaja yang bertingkah dengan hal-hal negatif, mereka tidak sadar bahwa hal itu akan menyebabkan keterpurukan terhadap hidupnya, bahkan akan menyebabkan kerugian yang besar bagi pribadi dan perkembangannya. Kenakalan-kenakalan yang dilakukan oleh seorang anak remaja sifat negatifnya sangat beragam misalnya pencopetan, narkotika, seks di luar nikah, pemerasan, pemerkosaan dan lain sebagainya. ${ }^{6}$ Pada masa ini akan timbul berbagai kemungkinan akan suatu perkembangan bagi anak. Perkembangan yang meliputi aspek fisik dan psikis yang akan membawa atau menimbulkan dampak baik bagi remaja itu sendiri, bahkan bagi orang tua dan orang-orang sekitarnya. Pada tahap remaja seorang anak mulai berusaha untuk mencari jati diri dan remaja yang sehat fisik maupun sehat mental, oleh karena itu dengan masa yang sangat intuitif, maka akan menyebabkan anak menjadi cepat stres, depresi dan lain sebagainya.

Hipnoterapi merupakan terapi yang dijalankan dengan menggunakan metode hipnosis. Hipnoterapi adalah aplikasi hipnosis dalam menyembuhkan gangguan mental dan meringankan gangguan fisik. Hipnosis telah terbukti secara medis, bahkan dapat mengatasi berbagai macam gangguan psikis maupun fisik. Hipnoterapi adalah sebuah penyembuhan dengan cara hipnotis. Hipnoterapi merupakan cabang ilmu psikologis yang mempelajari manfaat sugesti untuk mengatasi masalah pikiran, perasaan, dan perilaku, dengan memberikan sugesti ke pikiran bawah sadar. Dari beberapa pengertian diatas menurut penulis bahwa hipnoterapi merupakan salah satu terapi psikologis yang diterapkan oleh terapis (hipnosan) dengan metode hipnosis atau

\footnotetext{
${ }^{4}$ Ibid,. Hlm 3.

${ }^{5}$ Sumiati, "Kesehatan Jiwa Remaja dan Konseling", (Jakarta: Trans Indo Media, 2009).

${ }^{6}$ Desy Oktaviani dan Lukmawati, "Keharmonisan Keluarga dan Kenakalan Remaja pada Siswa Kelas 9 MTS Negeri 2 Palembang," Psikis: Jurnal Psikologi Islami, Vol. 4 No. 1, 2018. hlm 53.
} 
mengunakan sugesti berupa kata-kata (saran) kepada klien yang langsung menyentuh alam bawah sadar yakni pada saat tidur atau disaat pikiran klien hanya terfokus pada kata-kata terapis (hipnosan) dengan tujuan menyembuhkan permasalahan yang dihadapi oleh seorang klien (gangguan psikosomatis).

Hipnoterapi merupakan alat atau praktik yang bertujuan untuk membantu lebih dari puluhan permasalahan yang terjadi pada individu. Namun, hipnoterapi bukan berarti bisa mengobati atau memberikan rehabilitasi dari berbagai jenis penyakit, tetapi merupakan praktik yang memiliki fokus pada mentalitas individu. Menggunakan berbagai macam metode yang sangat efektif dalam membantu permasalahan pada seorang terutama bekerja dalam menghapus program-program negatif yang bersarang pada otak manusia. Sehingga hipnoterapi hadir setidaknya bisa menjadi cara untuk menghilangkan pemikiran negatif dan menggantikan dengan pemikiran positif. 7

Cahyadi menjelaskan penyembuhan perilaku negatif seseorang dapat dilakukan melalui penanaman sugesti dari dalam diri atau dilakukan langsung pada level pikiran bawah sadarnya, dengan cara menggunakan metode hipnoterapi. ${ }^{8}$ Karena hipnoterapi merupakan tindakan yang dilakukan dengan tujuan untuk menguasai pikiran seseorang yang akan diberikan pelayanan. Karena dalam merubah perilaku, itu juga bisa dengan melakukan pengondisian pada lingkungannya, juga dapat dilakukan dengan lebih meningkatkan dan menjalankan ajaranajaran agama yang dianut.

Selanjutnya Cahyadi memaparkan fungsi hipnoterapi bagi kehidupan manusia. Pertama, hipnoterapi dalam lingkup pendidikan, mampu memberikan penumbuhan kesadaran tingkat belajar dan meningkatkan kepercayaan diri seseorang. Kedua, Hipnoterapi dalam bidang psikologi yaitu untuk mengatasi masalah psikis seperti panik berlebih, stress, depresi, frustasi, sakit hati dan emosi negative. Ketiga, hipnoterapi untuk bidang kesehatan, seseorang dapat termotivasi untuk bisa lepas dari penyakitnya dan bisa meredakan sakit atau nyeri pada bagian tubuh tertentu akibat sakit yang anda derita.

Dari hasil observasi peneliti, salah seorang klien yang ditangani oleh hipnoterapi merupakan remaja muslim yang dahulunya memiliki watak baik. ${ }^{9}$ Tetapi disebabkan oleh perceraian orang tua, remaja muslim yang baik ini mendadak berubah menjadi ramaja yang nakal dan dekat dengan perilaku menyimpang. Remaja tersebut berhenti sekolah, kemudian melakukan berbagai perbuatan ekstrim di luar norma hingga pada akhirnya terjerat kasus berat

\footnotetext{
${ }^{7}$ Ibrahim, “Kesehatan Ala Hipnoterapi Islam,” Jurnal Ilmiah Syi'ar, Vol. 18, No. 2, 2018. hlm 103.

8 Ashadi Cahyadi, "Metode Hipnoterapi Dalam Merubah Prilaku," Jurnal Ilmiah Syi'ar, Vol. 17, No. 2, 2017. hlm 73-74.

${ }^{9}$ Data primer dari observasi dan wawancara, 21 Maret 2019.
} 
di Kepolisian wilayah Yogyakarta. Dari sisi ekonomi, sebenarnya remaja tersebut berlatar belakang keluarga yang kaya.

Untuk menyembuhkan perilaku negatif, orang tua (bapak) mengantarkan remaja tersebut ke Ikatan Hipnoterapis Indonesia (IHI) di Yogyakarta. Ini telah mendapat persetujuan langsung dari Kepolisian. IHI Yogyakarta merupakan lembaga hipnoterapi yang terlahir untuk memberikan kuratif pada klien yang memiliki gangguan psikis. Metode pengobatan yang digunakan adalah hipnotis. Juga dengan pemberian sugesti oleh ahli terapis melalui ransangan dan stimulus atas hal-hal yang bersifat positif kepada klien. Melangkah dari kasus tersebut, peneliti tertarik untuk mengkaji lebih dalam tentang bagaimana porses rehabilitasi klien kenakalan remaja pada praktik hipnoterapi di Ikatan Hipnoterapis Indonesia (IHI) Yogyakarta.

\section{METODE}

Penelitian ini termasuk dalam penelitian lapangan (Field Research), karena peneliti langsung terjun ke lokasi penelitian di kantor Lembaga Ikatan Hipnoterapis Indonesia (IHI) Yogyakarta. Tujuan dari penelitian ini untuk mendapatkan data yang valid terkait dengan proses rehabilitasi klien kenakalan remaja pada praktik hipnoterapi. Penelitian ini berlokasi di kantor Ikatan Hipnoterapis Indonesia (IHI) Yogyakarta. Metode pengumpulan data dalam penelitian ini menggunakan metode observasi, wawancara, dan dokumentasi di Lembaga Ikatan Hipnoterapis Indonesia (IHI) Yogyakarta. Kemudian responden dalam penelitian ini sebagai pemberi informasi terkait dengan proses rehabilitasi klien kenakalan remaja pada praktik hipnoterapi yakni pertama direktur dari lembaga ikatan hipnoterapi (IHI) yogyakarta dan informan kedua atau sekunder yakni staf dan asisten dari direktur Ikatan Hipnoterapis Indonesia (IHI) Yogyakarta.

\section{HASIL DAN PEMBAHASAN}

\section{Proses penerapan metode hipnoterapi dalam merubah prilaku remaja}

Praktik hipnoterapi hanya bisa dilakukan oleh ahli terapis yang sudah memiliki pengalaman. Standar umumnya adalah ahli terapis mampu memberikan kuratif terhadap kliennya yang memiliki bervariatif problem secara personal. Pada penelitian ini, praktik hipnoterapi memberikan orientasi rehabilitasi pada klien kenakalan remaja, Beberapa proses yang dilakukan dalam merehabilitasi klien kenakalan remaja pada prkatik hipnoterapi di Ikatan Hipnoterapis Indonesia (IHI) Yogyakarta.

Tahap tes sugestibilitas. Ini merupakan langkah awal untuk mengetahui kerelaan klien untuk dihipnotis. Terkadang banyak praktik hipnoterapi yang terjadinya kendala saat menangani klien, ketika kliennya belum siap untuk dihipnotis. Karenanya tes sugestibilitas merupakan suatu proses untuk menguji tingkat kerelaan klien untuk dihipnotis, sehingga klien akan terlihat 
apakah mudah atau sulit untuk disugesti. ${ }^{10} \mathrm{Di}$ awal, seorang ahli terapis harus menerima klien dengan baik, kemudian klien tersebut harus di-assessment. Caranya seperti ditanya latar belakang kehidupannya dan sampai masalah yang dihadapinya. Pada tahap ini, seorang klien harus rela dalam menceritakan masalahnya, dengan tujuan agar memudahkan proses rehabilitasi yang dilakukan oleh ahli terapis untuk memberikan kuratif terhadap masalah yang dihadapi oleh klien itu sendiri.

Pada level ini, praktik hipnoterapi memiliki klien seorang anak remaja yang sudah bertindak ekstrim dalam kehidupannya. Sehingga dalam membantu proses assessment pada level ini, dibantu oleh orang tua si anak. Bagaimanapun juga orang tua juga tahu bagaimana tindakan negatif pada anaknya. Namun, permasalahan pada anak ini diawali dengan pikiran stres akibat terjadinya broken home pada orang tuanya. Oleh karena itu, kecenderungan pada seorang anak dalam mengalami pribadi yang buruk itu lebih cenderung disebabkan oleh faktor keluarga dari pada lingkungan. Bahkan pada penelitian ini, seorang anak remaja tersebut, mengalami gangguan psikis akibat stres, kecewa, dan lain sebagainya.

Tahap pre-induction interview. Ini merupakan tahap dalam pelayanan hipnoterapi. Pada tahap ini, seorang ahli terapis membutuhkan waktu yang lama, karena harus memungkinkan klien atas praktik hipnotarapi agar memberikan hasil yang kondusif pada saat memberikan pelayanan untuk rehabilitasi permasalahan klien. Tahap ini dilakukan dengan memberikan wawancara untuk memberikan motivasi agar klien tidak takut pada praktik hipnoterapi. Fungsi dari pre induksi untuk membangun hubungan baik antara terapis dengan klien. Agar klien tidak membangun fikiran negatif terhadap praktik hipnoterapi bahwasannya praktik hipnoterapi merupakan praktik yang baik dan tidak berujung negatif. ${ }^{11}$ Dalam tahap ini, seorang klien remaja diberikan motivasi, bahkan ditanya cita-citanya oleh seorang terapis. Ketika seorang klien remaja tersebut ingin menjadi seorang tentara, sehingga dengan mudah seorang terapis mengetahui apa yang menjadi keinginan untuk masa depan kliennya. Karena posisi anak remaja sebagai generasi bagi suatu bangsa, anak pada usia remaja benar-benar harus diberikan motivasi yang baik agar bisa membantu kepribadiannya menjadi lebih baik, dan menjaganya dari hal-hal negative dan begaimana caranya agar terus mengeksploitasi hal-hal positif dalam kehidupannya.

Tahap induction. Ini merupakan tahap memasuki pikiran bawah sadar klien. Katika seorang terapis sudah menemukan maslah yang dihadapi klien. Karena itu pada tahap ini, seorang terapis harus memasuki pikiran bawah sadar klien. Pada tahap ini, dimana seorang klien harus dimulai dari kata-kata yang membuatnya rileks, duduk di kursi yang empuk dan mengikuti katakata dari seorang terapis. Anak remaja tersebut disuruh duduk dengan santai di kursi, sambil

${ }^{10}$ Subiyono, dkk. "Afirmasi Visualisasi dan Kekuatan Pikiran". (Yogyakarta: K-Media, 2015). hlm 43.

${ }^{11}$ Ibid., 43. 
melihat ibu jarinya dan mendengarkan kata-kata dari seorang terapis, setelah itu semakin rileks dan semakin tertidur hingga benar-benar mengalami ketidak sadaran.

Dalam rehabilitasi klien kenakalan remaja ini, karena proses yang dilaluinya sangat dekat dengan hal-hal yang membahayakan dirinya seperti radikal, mencuri dan lain sebagainya. Sehingga proses penenangan dalam pikiran bawah sadarnya dibiarkan selama seharian tertidur agar lebih rileks dan cepat tersugesti oleh kata-kata terapis. Pada tahap ini ahli terapis sudah menggunakan metode peralihan kesadaran terhadap gelombang otak klien ke bagian (subconcious mind) melalui metode Beta, Alpha, Teta, dan Deltha. Metode ini sudah menjadi metode wajib dalam pelayanan klien pada praktik hipnoterapi misalnya Beta keadaan sadar seorang klien, Alpha keadaan dimana klien sudah mulai khusus dan fokus pada praktik pelayanan hipnoterai, Teta dimana keadaan klien sudah mulai merangsang ke dalam pikiran bawah sadar, dan Deltha dimana keadaan klien sudah mulai memasuki pikiran bawah sadar, dan sudah siap untuk diberikan sugesti oleh seorang terapis untuk penyembuhan atau rehabilitasi.

Tahap deepening, merupakan tahap dimana klien sudah benar-benar tertidur dan tahap untuk pembimbingan klien dengan melakukan sugesti. Karena narasi sugesti merupakan tindakan ahli terapis untuk memberikan ransangan dan makna atas suatu peristiwa yang akan menjadi pengalaman baru bagi isi pikiran klien. ${ }^{12}$ Karena hipnoterapi merupakan pelayanan atau proses penyembuhan klien yang berorientasi langsung ke otak manusia. Sehingga ransangan akan benar-benar diterima secara baik oleh klien. Misalnya motivasi atau kata-kata yang dikatakan oleh ahli terapis sifatnya negatif maka klien akan negatif dan jika motivasi atau katakata yang diberikan oleh ahli terapis bersifat positif maka klien itu akan positif. Karena keadaan trance atau terhipnotis itu merupakan dimana keadaan manusia itu ibarat komputer kosong dan kata-kata dari sugesti yang diberikan oleh ahli terapis itu merupakan folder baru.

Dan pada tahap ini, pelayanan yang diberikan oleh ahli hipnoterapi dalam memberikan penyembuhan dan rehabilitasi terhadap kliennya tentu harus menggunakan sugesti dengan motivasi yang baik. Misalnya klien seorang anak remaja ini awalnya sangat ekstrim dan (bad behavior) atau bertindak buruk seperti mencuri, mabok, malas sekolah, dan lain sebagainya. Sehingga dalam merehabilitasi klien remaja pada praktik hipnoterapi menggunakan kata-kata pada proses sugesti itu lawan dari tindakannya tersebut, misalnya berhenti mabuk, rajin solat, rajin sekolah, berhenti menjadi pencuri, harus rajin belajar biar bisa jadi tentara sesuai keinginan dan cita-citanya. Selama proses tiga bulan lebih klien anak remaja itu dititip pada lembaga

12 Alyasinta Mulya W, "Peningkatan Kemampuan Menulis Narasi Sugestif melalui Penerapan Strategi Transition-Action-Details pada Peserta Didik Kelas XI SMK," Skripsi, Universitas Negeri Yogyakarta, 2015. hlm 14. 
hipnoterapi IHI Yogyakarta agar benar-benar menjadi pribadi yang positif dan tidak lagi menjadi anak remaja yang bertindak negatif.

Tahap depth level test, merupakan tahap melihat suatu hasil dari sugesti yang dilakukan pada tahap deeping, pada tahap ini seorang klien anak remaja itu masih dalam tahap proses rehabilitasi di hipnoterapi, akan tetapi dia sudah mulai merambat ke dunia positif seperti rajin solat, rajin sekolah, rajin olah raga. Dan intinya pada tahap ini seorang terapis melihat sejauh mana proses sugesti yang dilakukan untuk sebuah perbaikan kliennya.

Tahap termination, merupakan tahap melakukan normalisasi atas klien pada praktik hipnoterapi, misalnya perpindahan dari tahap trance ke tahap pikiran sadar klien. Karena pada masa sugesti dan pemasukan motivasi positif kepada klien, itu akan menjadi proses rehabilitasi dalam membuat klien menjadi pribadi yang baik. Dan ketika klien anak remaja itu sudah melalui tahap terminasi, remaja tersebut menjalankan sesuai dengan isi sugesti dari pelayanan hipnoterapi semasa pelayanan dan sugesti. Dimana klien tersebut rajin solat, rajin sekolah, dan lain sebagainya dan tidak lagi mekukan tindakan ekstrim atau hal-hal negative pada kehidupannya karena pikirannya sudah terisi dengan hal-hal positif yang mampu mengembangkan kehidupanya menjadi lebih baik. ${ }^{13}$

\section{Religiulitas sebagai Dampak Kuratif Hipnoterapi}

Peneliti mengamati ada perubahan sikap yang terjadi pada klien dapat singungkan dengan fenomena yang terjadi di lapangan, setidaknya peran hipnoterapi pada masalah yang diangkat di dalam tulisan ini peran hipnoterapi dalam meningkatkan moralitas klein ke tahap religiusitas. Dari uraian permasalahan yang terjadi, menunjukkan tindakan negatif dari klien, sehingga dengan ditangani oleh tangan terpais dengan menggunakan metode hipnoterapi, setidaknya memabngun moralitas klien. Disini penulis singungka dengan konsep atau teori hipnoterapi islam dari cabang psikologis yang mempelajari tentang nilai-nilai dan sugesti untuk mengatasi masalah klien guna dibawa atau ke arah islami yakni dengan meningkatkan moralitas atau religiusitas pada seorang klien. ${ }^{14}$

Membincangkan problematika kenakalan remaja yang ditangani dalam praktik hipnoterapi ini merupakan anak remaja mantan narapidana, yang dimana telah bertindak yang membahayakan dirinya juga psikologisnya. Akan tetapi, dengan melalui tindakan rehabilitasi hipnoterapi, mampu merubah prilaku negtaif pada anak menjadi berprilaku positif. Misalnya, dalam tahap merehabilitasi pada tahap deepening, dimana tahap ini merupakan tahap memulainya pembimbingan klien untuk menerima pesan-pesan positif dalam membantu merehabilitasi klien tersebut. Karena, hipnoterapi ini merupakan bentuk tindakan dalam

${ }^{13}$ Data primer dari observasi dan wawancara, 29 Maret 2019.

${ }^{14}$ Ibrahim, Kesehatan Ala Hipnoterapi Islam. hlm. 107. 
membantu psikologis klien yang menerima berbagai permasalahan, sehingga cara kerja dalam hipnoterapi ini, langsung ke dasar yakni langsung menyelami otak manusia dan seakan-akan ketika mengalami tahap tertidur dan trerhipnotis, seorang klien akan menjadi pendengan yang selalu menerima setiap ransangan dan sugest yang diberikan oleh seorang ahli terapis. Sehingga, dengan melalui rehabilitasi permasalahan klien yang berbaur dengan psikolgisnya, setiap ahli terapis seakan-akan menjadi orang yang memberi bimbingan bagi klien, karena setiap yang dikatakan oleh terapis pada saat sugesti, selalu akan diterima oleh seorang klien yang dalam keadaan terhiupnotis.

Setelah melalui tahap rehabilitasi hipnoterapi, klien kenakalan remaja menjadi anak yang bermoral dan berhenti dalam melakukan hal-hal negatif. Dampak dari rehabilitasi hopnoterapi yakni. Pertama, klien anak remaja menjadi berprilaku positif dan menghilangkan prilaku-prilaku negatif seperti mencuri, malas sekolah dan lain sebagainya. Kedua, klien anak remaja menjadi lebih bermoral dengan sifat kereligiusitasnya seperti melakukan ibadah, seperti rajin sholat tanpa harus mendengar sebuah saran atau nasehat, akan tetapi setidaknya dengan jalan hipnoterapi, membuat dirinya menjadi lebih religius dan spritualis. Sehingga hipnoterapi tidak hanya bisa menyembuhkan permasalahn secara fisik, akan tettapi secara substansi memang bertitik pada permasalahan otak atau fikiran individu, tidak heran jika melihat teori dari hipnoterapi memang bertujuan atau berorientasi pada pikiran manusia dengan menyapu program negatif dan digantikan dengan program positif atau pikiran yang positif yang bisa membuat diri manusia itu menjadi lebih baik.

Dari tingkat pealihan yang terjadi setelah menjalankan proses rehabilitasi melalui metode hipnoterapi, tentu keliatan hasil yang kondusi fada anak remaja, mencapai suatu hasil yang mendirikan moralitasnya menjadi positif. Berbicara tentang moral, moral merupapkan tanda baik atau buruk pada karaakteristik manusiawi. Secara bahasa moral berasal dari kata mores yang beratrti tindakan, kebiasaan, prilaku dan adat dalam kehidupan. Sehingga penting kiranya, moralitas pada diri seorang manusia harus menimba hal-hal kebajikan agar menjamin menjadi pribadi yang baik dan memiliki nilai (value) positif pula di mata manusia yang lain. ${ }^{15}$

\section{KESIMPULAN}

Studi ini berorientasi pada proses dan dampak rehabilitasi kenakalan remaja dengan melalui metode praktik hipnpoterapi di Ikatan Hipnoterapis Indonesia (IHI) Yogyakarta. Proses yang digunakan oleh hipnoterapi untuk merehabilitasi kenakalan remaja yakni menggunakan beberapa tahap yakni: a) Tes sugestibilitas dan per-induction interview, mengumpulkan informasi terkait permasalahan klien agar memudahkan proses rehabilitasi; b) Induction, memasuki tahap

${ }^{15}$ M. Nikam Naser, “Konselor dalam Penguatan Nilai dan Moral: Strategi Membentuk Generasi Religius," Jurnal Ilmiah Syiar, Vol. 19, No 01, 2019. hlm 34. 
peralihan kesadaran klien ke pikiran bawah sadar, agar lebih mudah untuk di rehabilitasi dari permasalahannya yang ekstrim atau bad behavior dengan melalui metode Beta, Alpha, Teta, dan Deltha.

Selanjutnya, Deepening dimana anak remaja sudah melalui tahap tidak sadar dan mulai tahap pembimbingan untuk dimotivasi dengan kata-kata positif atau lawan dari tindakakan negative yang sering dilakukan yang menjadi kebiasaanya sebelum direhabilitasi degan metode hipnoterapi (d) Depth level test, tahap melihat melihat suatu hasil dari rehabilitasi klien kenakalan remaja seperti perkembangnnya yang negatif ke tahap positif msialnya sudah mulai rajin solat, sekolah dan lain sebagainya yang berbau positf dalam kehidupan sehari-harinya (e) Termination, tahap pengembalian pikiran sadar klien dari alam tidak sadarnya ketika melalui proses hipnotis oleh seorang terapis. Namun dalam tahap ini klien sudah disugesti dan pikirannya sudah terisi dengan hal-hal positif dari hasil sugesti yang dilakukan oleh ahli terapis pada saat rehabilitasi klien, dan dampak dalam menjalankan proses hipnoterapi, tentu menghasilkan yang jauh menjadi pribadi yang baik, semisal prilaku negatif yang sering dilakukan oleh anak remaja menjadi berprilaku positif, bahkan menjadi anak yang religius seperti rajin sekolah dan rajin beribadah.

\section{DAFTAR RUJUKAN}

Budiman. "Efektifitas Hypnoterapi Teknik Anchor Terhadap Perubahan Perilaku Merokok Remaja." Psikis-Jurnal Psikolog Islam, Vol.2 No. 2, 2006.

Cahyadi, Ashadi. “Metode Hipnoterapi dalam Merubah Prilaku.” Jurnal Ilmiah Syi'ar, Vol. 17 No. 2, 2017.

Ibrahim. “Kesehatan Ala Hipnoterapi Islam.” Jurnal Ilmiah Syi’ar, Vol. 18, No. 2, 2018.

Nalendra, Alguskha. "The Big Book of Professional Hypnotherapist". Malang: Litera Media Tama, 2017.

Naser, M. Nikam. “Konselor dalam Penguatan Nilai dan Moral: Strategi Membentuk Generasi Religius." Jurnal Ilmiah Syiar, Vol. 19, No 01, 2019.

Shanty, Ida Nor., Suyahmo., dan Slamet Sumarto. "Faktor Penyebab Kenakalan Remaja Pada Anak Keluarga Buruh Pabrik Rokok Djarum Di Kudus." Unnes Civic Education Journal, Vol. 1, No. 2, 2015.

Oktaviani, Desy, and Lukmawati. "Keharmonisan Keluarga dan Kenakalan Remaja pada Siswa Kelas 9 MTS Negeri 2 Palembang." Psikis: Jurnal Psikologi Islami, Vol. 4 No. 1, 2018.

Sejati, Sugeng. "Implikasi Egosentris dan Spritual Remaja dalam Mencapai Perkembangan Identitas Diri." Jurnal Ilmiah Syiar, Vol. 19, No. 1, 2019.

Subiyono, dkk. Afirmasi Visualisasi dan Kekuatan Pikiran. Yogyakarta: Penerbit K-Media, 2015. 
Sumiati. “Kesehatan Jiwa Remaja dan Konseling.” Jakarta: Trans Indo Media, 2009.

W, Alyasinta Mulya. "Peningkatan Kemampuan Menulis Narasi Sugestif melalui Penerapan Strategi Transition-Action-Details pada Peserta Didik Kelas XI SMK." Skripsi. Universitas Negeri Yogyakarta, 2015.

Wahyuningsih, Indah. "Hubungan Pikiran dan Bahasa pada Bahasa Hypnotherapy." Skripsi, Universitas Muhammadiyah Surakarta, 2015.

Widyastuti, Dian. “Reintegrasi Sosial Orang dengan Gangguan Jiwa Pasca Program Layanan Lanjutan pada Rumah Singgah." Tesis, Uin Sunan Kalijaga Yogyakarta, 2018.

Wise, Anna. "Kekuatan Gelombang Otak". Jakarta: Gramedia, 2011. 